
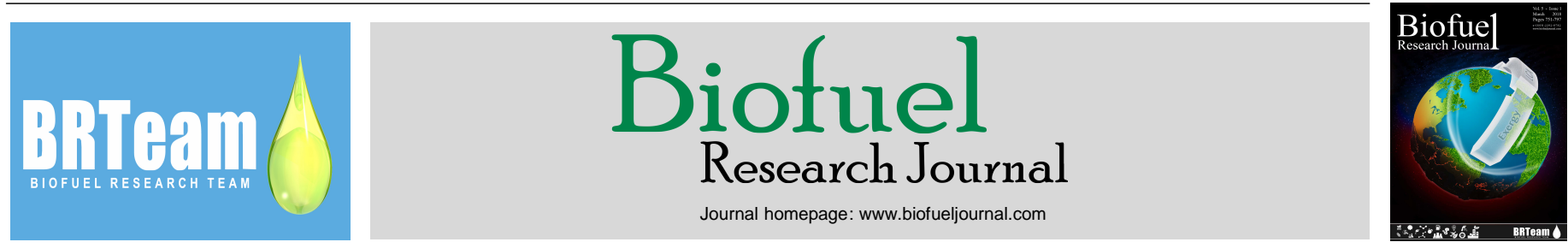

Short Communication

\title{
Synthesis of solketalacetin as a green fuel additive via ketalization of monoacetin with acetone using silica benzyl sulfonic acid as catalyst
}

\author{
Hassan S. Ghaziaskar*, Yadollah M. Gorji \\ Department of Chemistry, Isfahan University of Technology, Isfahan, 84156-83111, Iran.
}

\section{HIGHLIGHTS}

$>$ Silica benzyl sulfonic acid (SBSA) was prepared as a catalyst for reacting monoacetin with acetone to synthesize solketalacetin as a green fuel additive. $>$ SBSA was synthesized using a commercially available silica gel.

> The catalytic activity of SBSA was superior to Amberlyst 36 and Purolite PD 206.

$>$ Increasing acetone to monoacetin mole ratio

increased solketalacetin yield with SBSA leading to the highest yield.

- Solketalacetin yield was reduced with temperature increase for all the catalysts.

$>$ Maximum solketalacetin yield with Amberlyst 36 and SBSA were recorded at 20 and $40^{\circ} \mathrm{C}$, respectively.

\section{GRAPHICAL ABSTRACT}

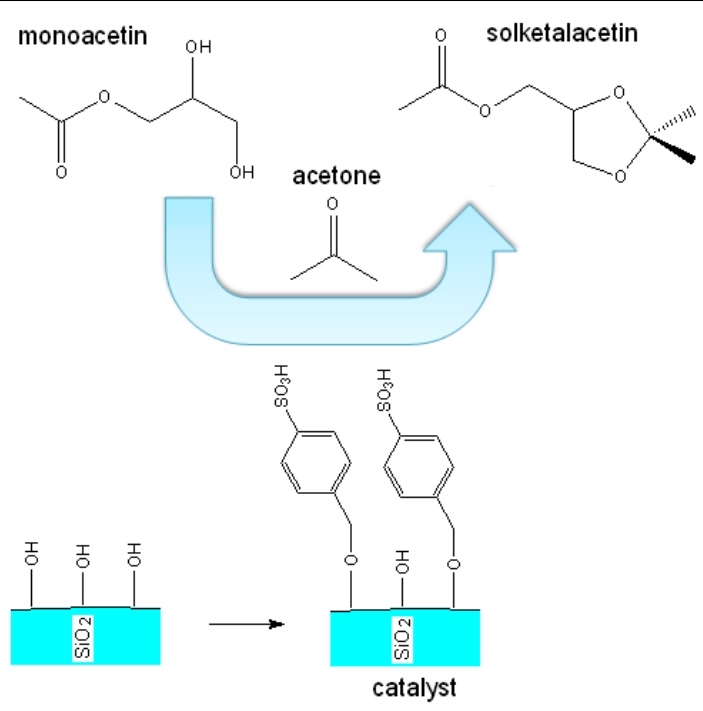

\section{ARTICLE INFO}

Article history:

Received 21 December 2017

Received in revised form 15 February 2018

Accepted 16 February 2018

Available online 1 March 2018

\section{Keywords:}

Monoacetin

Acetylation

Solketalacetin

Biodiesel

Fuel additive

\begin{abstract}
Silica benzyl sulfonic acid (SBSA) was prepared as a catalyst for reacting monoacetin with acetone to synthesize solketalacetin as a green fuel additive. To synthesize SBSA, commercially available silica gel was functionalized with benzyl alcohol in the presence of sulfuric acid as catalyst and was then sulfonated with chlorosulfonic acid. The catalyst was characterized by FT-IR, XRD, and TGA. The catalytic activity of SBS A was compared with those of Amberlyst 36 and Purolite PD 206 as two sulfonated acidic catalysts, in a continuous flow system. The effect of different operation conditions such as acetone to monoacetin molar ratio, reaction temperature, and feed flow rate were investigated. Increasing acetone to monoacetin molar ratio increased the solketalacetin yield for the three catalysts but SBSA demonstrated the highest solketalacetin yield. Solketalacetin yield was reduced with temperature increase for all the catalysts and the maximum solketalacetin yields were recorded with Amberlyst 36 and SBS A catalyst at $20^{\circ} \mathrm{C}$ and $40^{\circ} \mathrm{C}$, respectively. The catalytic activity was examined by keeping the catalysts on-stream for $25 \mathrm{~h}$ while the reusability tests were performed in four consecutive runs and showed that SBSA was stable up to $25 \mathrm{~h}$ and had the highest stability in 4 runs.
\end{abstract}

* Corresponding author at: Tel.: +98 3133913260

E-mail address: ghazi@cc.iut.ac.ir

Please cite this article as: Ghaziaskar H.S., Gorji Y.M. Synthesis of solketalacetin as a green fuel additive via ketalization of monoacetin with acetone using silica benzyl sulfonic acid as catalyst. Biofuel Research Journal 17 (2018) 753-758. DOI: 10.18331/BRJ2018.5.1.3 


\section{Introduction}

Environmental pollution and global warming are among the most significant international concerns caused by widespread use of fossil fuels. To address these concerns, renewable energy carriers such as biofuel (e.g., biodiesel, bioethanol, etc.) have attracted a great deal of attention as alternatives to fossiloriented fuels (Goncalves et al., 2016). Among biofuels, biodiesel mainly produced via transesterification of vegetable oil triglycerides with methanol in the presence of an alkaline catalyst (e.g., $\mathrm{NaOH}$ ), is largely utilized all around the word as mineral diesel replacement. Through this reaction, glycerol is also produced as a principal byproduct called crude glycerol (Kim et al., 2004; Gerpen et al., 2005). It is estimated that $\sim 10$ wt. $\%$ of the total biodiesel produced is crude glycerol (Johnson et al., 2009), mostly regarded as waste. This huge amount of glycerol could pose serious environmental threats if disposed of into the environment due to its highly organic nature. On the other hand, given its quantity, its efficient utilization with the aim of producing valueadded products is highly advisable. This could also enhance the economic viability of the biodiesel industry. In line with that, efforts have been put into converting crude glycerol into a wide range of products including fuel additives.

Some of glycerol derivatives such as glycerol ketals as well as acetals including diacetin, triacetin, and solketal have been used as oxygenated fuel additives so far (Zhou et al., 2008; Rezayat et al., 2009; Fan et al., 2010; Mota et al., 2010; Silva et al., 2010; Shirani et al., 2014; Rastegari et al., 2015; Shafiei et al., 2017). Among these, solketalacetin ((2,2-dimethyl-1,3-dioxolan-4yl)methyl acetate) is considered as a biodiesel additive leading to improved viscosity and flash point (Garcia et al., 2008). Solketalacetin is synthesized through the reaction of glycerol with acetone and acetic anhydride (Garcia et al., 2008).

Other acidic catalysts can also be used to catalyze the reaction between monoacetin and acetone. In line with that, numerous catalysts have been investigated for the acetalization and ketalization of glycerol to date. For instance, homogeneous catalysts including sulfuric acid, hydrofluoric acid, and paratoluene sulfonic acid were used for valorization of glycerol to ketals and acetals (Cablewski et al., 1994; Krief et al., 1998). However, homogeneous catalysts could cause corrosion problems and their application is associated with unfavorable environmental impacts. Moreover, the processes involved in separating these catalysts from the products are ineffective and costly.

On the contrary, using heterogeneous catalysts for the synthesis of fuel additives from glycerol, higher purity of final reaction products and easier recovery can be achieved. The main heterogeneous catalysts used for ketalization and acetalization reaction include niobium-zirconium oxide catalysts (Lauriol-Garbey et al., 2011), HZSM-5, HUSY, K-10 montmorillonite (Deutsch et al., 2007; Goncalves et al., 2008), heteropolyacids (Bhorodwaj et al., 2011), PMo-NaUSY (Ferreira et al., 2009), mesoporous silica (Melero et al., 2007), Nafion-H NR-50, H-BEA, Amberlyst-36 (Deutsch et al., 2007; Mota et al., 2010; Nanda et al., 2014), Amberlyst 15 (Zhou et al., 2013), Zeolite beta (Maksimov et al., 2011; Nanda et al., 2014), and $\mathrm{MoO}_{3} / \mathrm{SiO}_{2}$ (Umbarkar et al., 2009). Another category of heterogeneous catalysts used to catalyze ketalization and acetalization reactions is cation-exchange resins which have been shown to have a higher activity as well as excellent selectivity for desired products in comparison with other heterogeneous catalysts (Klepacova et al., 2005; Goncalves et al., 2008). In our previous works, a method was developed for economical synthesis of solketalacetin in two stages using a type cation-exchange resin catalyst, namely Purolite PD 206 (Gorji et al., 2016 and 2018). More specifically, in the first stage, monoacetin was synthesized through the reaction of glycerol with acetic acid. In the second stage, solketalacetin was obtained through the reaction of monoacetin with acetone in the presence of Purolite PD 206 as catalyst. In spite of the promising results obtained, the catalyst used suffer from a number of drawbacks including low reusability, leaching of the sulfonic acid group from the catalyst, and reduction of the catalyst activity vs. time (Gorji et al., 2016). It should also be mentioned that Purolite PD 206 is costly.

Therefore, the aim of this study was to develop a novel process for the ketalization of monoacetin with acetone to synthesize solketalacetin using a more stable and economically-viable catalyst. More specifically, silica benzyl sulfonic acid (SBSA) catalyst was synthesized from a commercially available silica gel which could also be used in a continuous system. Moreover, the performance of the synthesized SBSA catalyst was compared with those of the Amberlyst 36 and Purolite PD 206.

\section{Experimental}

\subsection{Materials and Methods}

Silica gel was purchased from Silicagel Derakhshan Co. (Tehran, Iran). Acetone (purity $>99 \%$ ), acetic acid and methanol (purity $>99.85 \%$ ), and Glycerol (purity > 99.9\%) were purchased from Sasol Co. (Johannesburg, South Africa), Fanavaran Petrochemical Co. (Assaluyeh, Iran), and Emery Oleochemicals (Kuala Lumpur, Malaysia), respectively. Diacetin (purity $\sim 50 \%$ ) and triacetin (purity > 99\%) were purchased from Fluka (Seelze, Germany). Solketal, monoacetin, and solketalacetin were synthesized via the method reported previously (purity > 95\% verified by Gas Chromatography - Flame Ionization Detector (GC-FID)) (Garcia et al., 2008; Zhou et al., 2012). Purolite PD 206 was obtained from Purolite Co. (USA). Amberlyst 36 was purchased from Sigma-Aldrich (Munich, Germany). 2-Ethyl-1-hexanol was purchased from Arak Petrochemical Co. (Arak, Iran).

\subsection{SBSA catalyst preparation}

SBSA was prepared based on the published procedures with some modifications (Kumar et al., 2001; Najafi et al., 2015). First, $3.0 \mathrm{~g}$ of silica gel was kept in a solution of $0.1 \mathrm{~mol} \mathrm{HCl}$ for $24 \mathrm{~h}$ under reflux condition at $90{ }^{\circ} \mathrm{C}$. The resulted solid was filtered, washed, and dried under vacuum condition at $250^{\circ} \mathrm{C}$. Dried solid $(2.0 \mathrm{~g})$ was added to $10 \mathrm{~mL}$ benzyl alcohol dissolved in $20 \mathrm{~mL}$ toluene in the presence of sulfuric acid and refluxed with dean stark for $48 \mathrm{~h}$. After filtering, washing, and drying, the resulted solid was sulfonated with chlorosulfonic acid in chloroform under reflux condition for $4 \mathrm{~h}$ to produce SBSA catalyst. Finally, the SBSA catalyst was filtered, washed, and dried at $100^{\circ} \mathrm{C}$.

\subsection{Monoacetin synthesis}

Monoacetin was synthesized through the reaction of acetic acid and glycerol in a continuous flow system (Fig. 1). A plug flow reactor with 8 $\mathrm{mm}$ internal diameter and $3.2 \mathrm{~cm}$ length, containing $0.9 \mathrm{~g}$ of Amberlyst 36 as catalyst was placed in an oven equipped with a temperature controller $\left( \pm 1{ }^{\circ} \mathrm{C}\right)$. The pressure $( \pm 1$ bar) was created via a backpressure regulator (model BP 1580-81, JASCO Co.). Feedstock solution was pumped into the reactor continuously using a high-performance liquid chromatography (HPLC) pump (model PU-980, JASCO Co.) (Fig. 2). Samples were collected in a cold trap and analyzed by GC-FID. The optimum conditions for the reaction of acetic acid and glycerol were obtained in our previous work, i.e., reaction temperature of $78{ }^{\circ} \mathrm{C}$, acetic acid to glycerol mole ratio of 3.7:1, pressure of $1 \mathrm{bar}$, and the feed flow rate of $0.9 \mathrm{~mL} \cdot \mathrm{min}^{-1}$ (Gorji et al., 2018). Reaction of glycerol and acetic acid was conducted under these optimum conditions to obtain a mixture with the following mole percent; remaining glycerol $(30 \%)$, monoacetin $(62 \%)$, and diacetin $(8 \%)$. The solution was then vacuum distilled to remove water and acetic acid from the mixture.
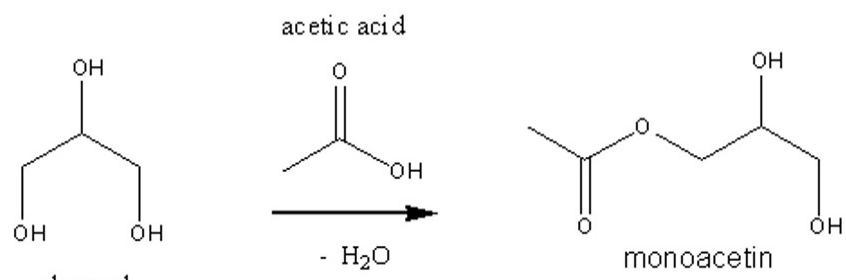

glycerol

Fig. 1. Reaction of glycerol with acetic acid to produced monoacetin.

\subsection{Sample analysis}

Analysis of the samples in different experiments was conducted by a GC-FID (model SP-3420, Beifen-Ruili Analytical Instrument Co., Ltd., Beijing, China). An HP-5 capillary column with $30 \mathrm{~m}$ length, $0.25 \mathrm{~mm}$ i.d., 


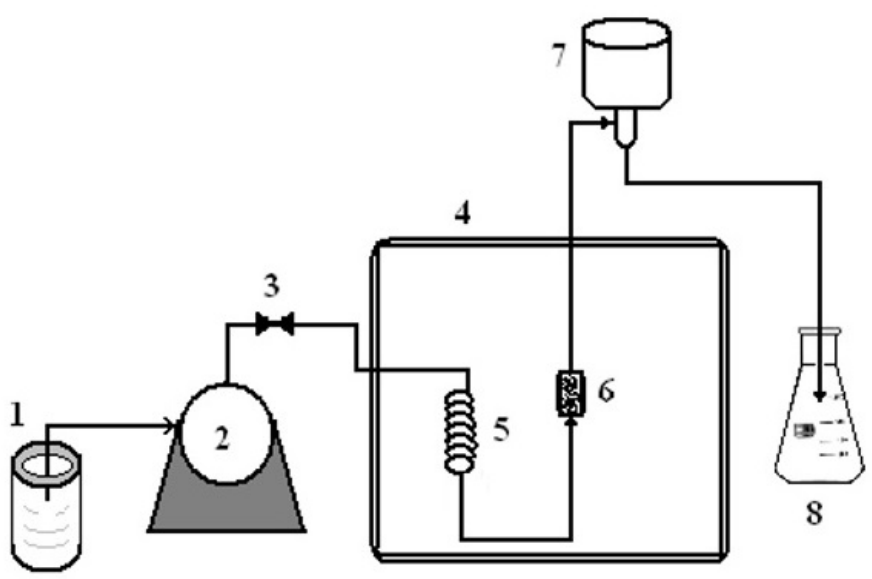

Fig. 2. The schematic diagram of the setup used for the reaction of glycerol and acetic acid; 1: Feedstock reservoir, 2: HPLC pump, 3: On-off valve, 4: Oven, 5: Preheating coil, 6: Reactor, 7: Back-pressure regulator, and 8: Sample collection vessel.

and $0.25 \mu \mathrm{m}$ film thickness was used and the carrier gas was argon. The GC injection port and the detector temperatures were set at $290{ }^{\circ} \mathrm{C}$ and $300{ }^{\circ} \mathrm{C}$, respectively. The temperature programing used for the GC analysis was as follows: initial column temperature was set at $80^{\circ} \mathrm{C}$ for $3 \mathrm{~min}$, then increased from $80{ }^{\circ} \mathrm{C}$ to $90{ }^{\circ} \mathrm{C}$ at the rate of $3{ }^{\circ} \mathrm{C} \cdot \mathrm{min}^{-1}$, and from $90{ }^{\circ} \mathrm{C}$ to $280{ }^{\circ} \mathrm{C}$ at the rate of $35^{\circ} \mathrm{C} \cdot \mathrm{min}^{-1}$. Finally, it was held at $280^{\circ} \mathrm{C}$ for $5 \mathrm{~min}$. The quantification was performed by injecting an internal standard (2-ethyl-1-hexanol) and integrating the peak areas to establish the calibration curve. Methanol was used as solvent in sample preparations and then $0.4 \mu \mathrm{L}$ of the sample was injected into the GC-FID.

The yield of the solketalacetin was calculated using Equation 1:

Yield $(\%)=\frac{\text { Moles of solketalacetin }}{\text { Initial moles of monoacetin }} \times 100$

\section{Results and Discussion}

\subsection{Catalyst characterization}

To prepare the SBSA catalyst, silica gel was refluxed in a solution of hydrochloric acid $0.1 \mathrm{M}$ for $24 \mathrm{~h}$. After drying, the remaining solid was refluxed in a solution of benzyl alcohol and toluene to react silica with benzyl alcohol in the presence of sulfuric acid and finally the sulfonation reaction was conducted with chlorosulfonic acid as shown in Figure 3.
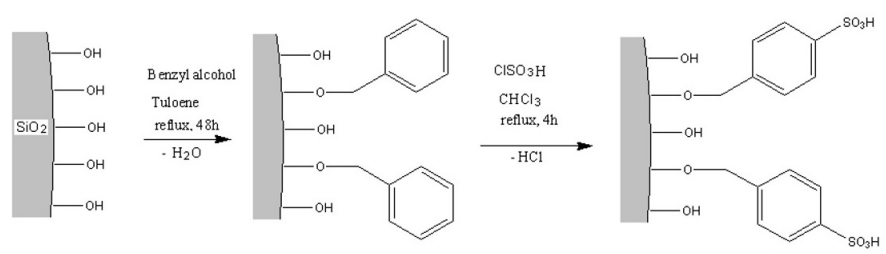

Fig. 3. Synthesis flowchart of SBSA as catalyst.

Preparation of the SBSA catalysts was monitored by FT-IR spectroscopy via the $\mathrm{KBr}$ dilution technique. Figures $4 \mathrm{a}$, b, and $\mathrm{C}$ show the FT-IR spectra of the protonated silica gel in $\mathrm{HCl}$, benzylated silica, and SBSA catalyst, respectively. The band observed at $1050 \mathrm{~cm}^{-1}$ was attributed to the stretching vibration of Si$\mathrm{O}-\mathrm{Si}$ groups. The bands appearing at $2850-3100 \mathrm{~cm}^{-1}$ reveals the $\mathrm{C}-\mathrm{H}$

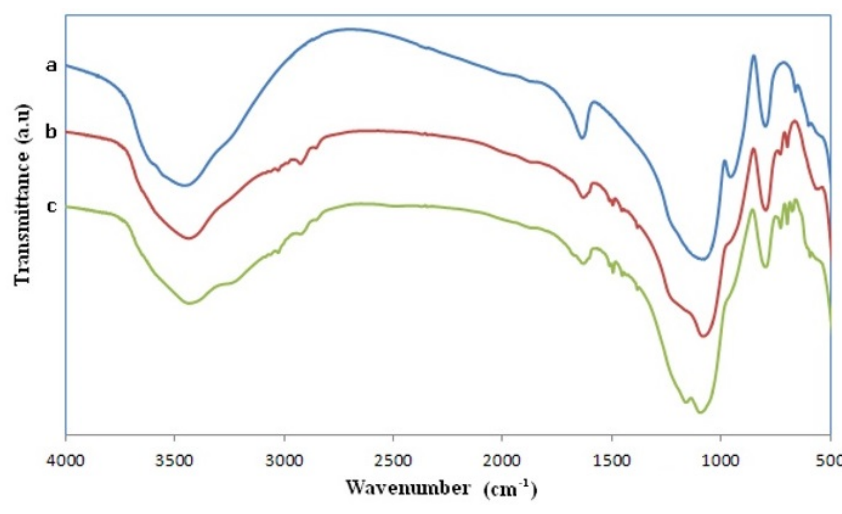

Fig. 4. FT-IR spectra of the silica gel in $\mathrm{HCl}$ (a), benzylated silica (b), and silica benzyl sulfonic acid (SBSA catalyst) (c).

asymmetric and symmetric stretching of methylene group after benzylation of silica (Figs. $4 \mathrm{~b}$ and c). The broadband observed at $3000-3500$ (Fig. 4c) could be attributed to the acidic $\mathrm{O}-\mathrm{H}$ groups after sulfonation. The sulfonic acid related bonds were observed at 650 and $1000-1200 \mathrm{~cm}^{-1}$ corresponding to the $\mathrm{S}=\mathrm{O}$ stretching vibration of sulfonic groups and the $\mathrm{O}=\mathrm{S}=\mathrm{O}$ symmetric and asymmetric stretching modes, respctively (Miyatake et al., 1996). Figure 5 shows the X-ray diffraction pattern of silica gel, benzyl silica, and SBSA catalyst revealing the amorphous structure of the silica (Shokrolahi et al., 2012; Sivasankaran et al., 2016).

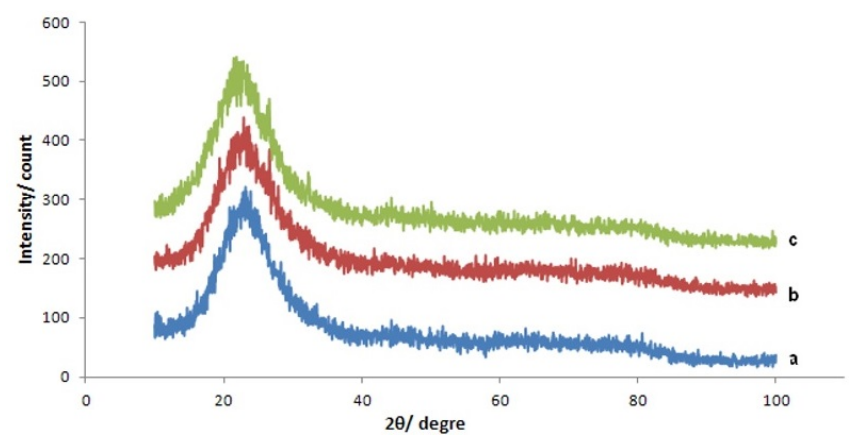

Fig. 5. X-ray diffraction patterns of the silica gel in $\mathrm{HCl}$ (a), benzylated silica (b), and silica benzyl sulfonic acid catalyst (c).

Figure 6 presents the thermograms of thermogravimetric analysis (TGA) of silica gel in $\mathrm{HCl}$, benzylated silica, and SBSA catalyst. The protonated silica gel showed a weight loss in the temperature range of 100 $200{ }^{\circ} \mathrm{C}$ due to the elimination of surface-adsorbed water. While the benzylated silica showed a distinct weight loss at $350-450{ }^{\circ} \mathrm{C}$ due to loss of benzyl groups. The TGA of the SBSA catalyst showed two significant weight losses at $200-3500^{\circ} \mathrm{C}$ and $350-450{ }^{\circ} \mathrm{C}$ due to the loss of sulfonic and benzyl groups, respectively (Guimaraes et al., 2009; Sasikala et al., 2014). The acidity of the SBSA catalyst determined using an inverse acid-base titration stood at $5.8 \mathrm{mmol} . \mathrm{g}^{-1}$ acid content.

\subsection{Catalyst activity}

Solketalacetin formation via monoacetin ketalization with acetone (Fig. 7) was conducted in a continuous flow system. The reactor was filled with 


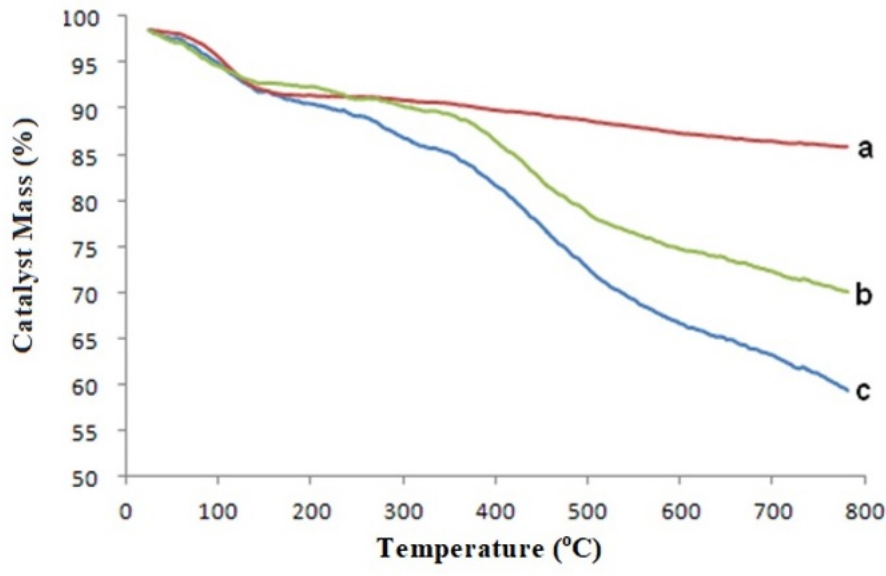

Fig. 6. TGA diagrams of the silica gel in $\mathrm{HCl}$ (a), benzylated silica (b), and silica benzyl sulfonic acid catalyst (c)

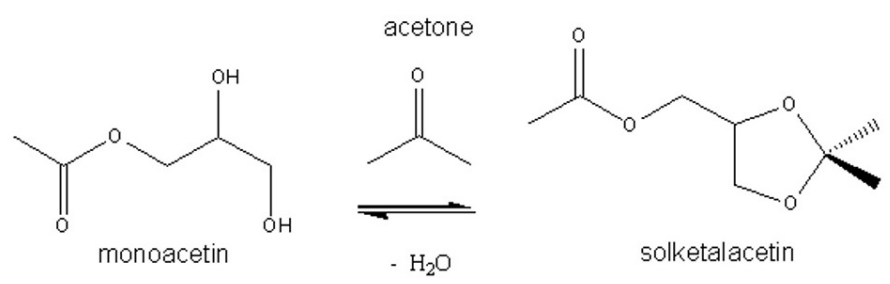

Fig. 7. Reaction of monoacetin with acetone to produced solketalacetin.

$1.0 \mathrm{~g}$ of each catalyst separately (i.e., SBSA, Amberlyst 36, and Purolite PD 206) and the feedstock solution was continuously pumped into the reactor.

The effect of acetone to monoacetin molar ratio on the yield of solketalacetin was investigated for each catalyst. The results of solketalacetin yield with different acetone to monoacetin molar ratio at $40{ }^{\circ} \mathrm{C}, 1 \mathrm{bar}$, and $0.4 \mathrm{~mL} \cdot \mathrm{min}^{-1}$ feed flow rate are summarized in Table 1. It is clear that by increasing the acetone to monoacetin molar ratio, the solketalacetin yield was increased. As shown in Table 1, the SBSA led to the highest solketalacetin yield which could be ascribed to the high acidity strength of SBSA. It has been reported that the rate of the ketalization reaction is correlated with the acidity of the catalyst used (Kumar et al., 2001; Nanda et al., 2014). The acidity of Amberlyst 36, Purolite PD 206, and SBSA catalyst was 5.6, 4.9, and $5.8 \mathrm{mmol} . \mathrm{g}^{-1}$, respectively.

Table 1.

Effect of acetone to monoacetin molar ratio on solketalacetin yield with $1.0 \mathrm{~g}$ catalyst and at 40 ${ }^{\circ} \mathrm{C}$ reaction temperature, $1 \mathrm{bar}$, and $0.4 \mathrm{~mL} \cdot \mathrm{min}^{-1}$ feed flow rate.

\begin{tabular}{lccc}
\hline & \multicolumn{3}{c}{ Acetone to monoacetin molar ratio } \\
\cline { 2 - 4 } Catalyst & $\mathbf{2}$ & $\mathbf{4}$ & $\mathbf{6}$ \\
\cline { 2 - 4 } & \multicolumn{3}{c}{ Solketalacetin yield (\%) } \\
\hline Amberlyst 36 & 37 & 9 & 72 \\
Purolite PD 206 & 35 & 46 & 67 \\
SBSA & 39 & 51 & 74 \\
\hline
\end{tabular}

The effect of temperature on the reaction of monoacetin with acetone was investigated at four different temperature values (i.e., $20,40,60$, and $80^{\circ} \mathrm{C}$ ) in acetone to monoacetin molar ratio of $5,1 \mathrm{bar}, 0.4 \mathrm{~mL} \cdot \mathrm{min}^{-1}$ feed flow rate and
$1.0 \mathrm{~g}$ of each catalyst used separately (Amberlyst 36, Purolite PD 206 and SBSA) (Fig. 8). At $20^{\circ} \mathrm{C}$, the maximum solketalacetin yield was observed with Amberlyst 36 but at $40^{\circ} \mathrm{C}$, the highest yield was observed with SBSA catalyst. In general, for all three catalysts, solketalacetin yield was reduced with increasing temperature, since ketalization is an exothermic reaction and higher reaction temperatures could lead to lower solketalacetin yields (Maksimov et al., 2011; Nanda et al., 2014).

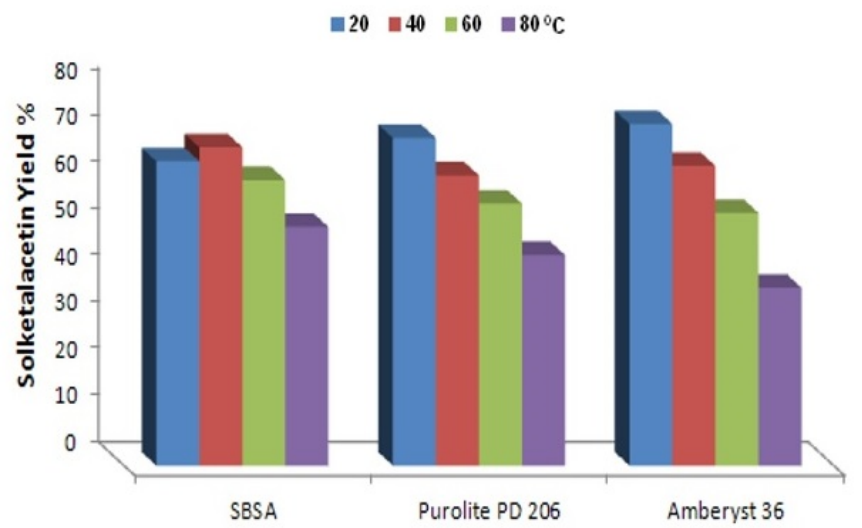

Fig. 8. The effect of temperature on the solketalacetin yield at four different temperatures (i.e., 20,40,60, and $80^{\circ} \mathrm{C}$ ), in acetone to monoacetin molar ratio of $5,1 \mathrm{bar}, 0.4 \mathrm{~mL} \cdot \mathrm{min}^{-1}$ feed flow rate, and $1.0 \mathrm{~g}$ of each catalyst separately (i.e., Amberlyst 36, Purolite PD 206, and SBSA).

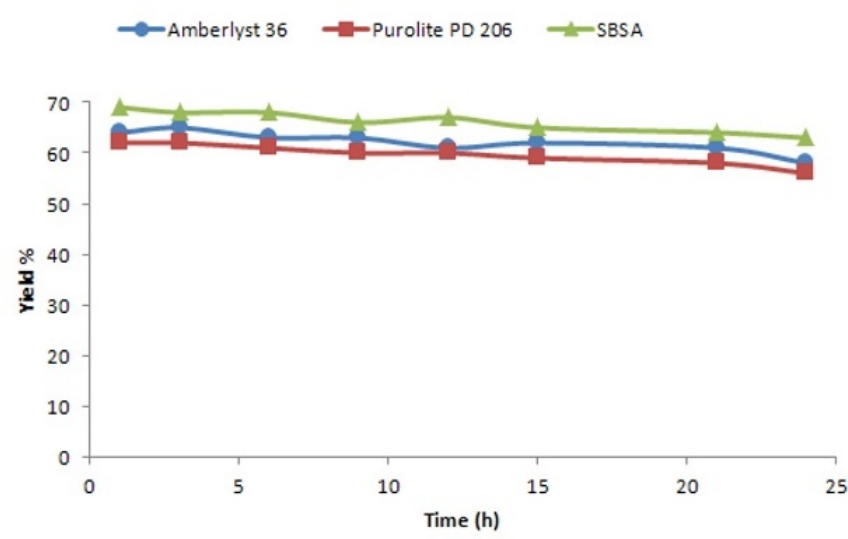

Fig.9. The reaction yield (\%) vs. time-on-stream for $24 \mathrm{~h}$ under acetone to monoacetin molar ratio of $5,1.0 \mathrm{~g}$ of each catalyst (Amberlyst 36 , Purolite PD 206, and SBSA), $40{ }^{\circ} \mathrm{C}$ reaction temperature, $1 \mathrm{bar}$, and $0.4 \mathrm{~mL} \cdot \mathrm{min}^{-1}$ feed flow rate.

The catalysts stability was also determined by keeping the catalysts onstream for $24 \mathrm{~h}$ in acetone to monoacetin molar ratio of $5,1.0 \mathrm{~g}$ catalyst, 40 ${ }^{\circ} \mathrm{C}$ reaction temperature, $1 \mathrm{bar}$, and $0.4 \mathrm{~mL} \cdot \mathrm{min}^{-1}$ feed flow rate. Figure 9 shows the activity of the catalysts $v s$. time, demonstrating that the catalysts were stable for at least $24 \mathrm{~h}$. The reusability of the catalysts was examined by recycling the catalyst for four runs. Each catalyst was kept on-stream for $2 \mathrm{~h}$ in acetone to monoacetin molar ratio of $5,1.0 \mathrm{~g}$ catalyst, $40^{\circ} \mathrm{C}$ reaction temperature, $1 \mathrm{bar}$, and $0.4 \mathrm{~mL} \cdot \mathrm{min}^{-1}$ feed flow rate. After each run, the catalysts were regenerated by washing with methanol followed by drying in an oven at $70{ }^{\circ} \mathrm{C}$ for $5 \mathrm{~h}$. Subsequently, the catalysts were reused under 
similar conditions to those of the first experiment. Figure 10 shows the results obtained on the reusability of the catalysts for solketalacetin synthesis. Accordingly, SBSA presented more favorable stability and catalyst activity for the solketalacetin synthesis. These results suggest that SBSA catalyst prepared from commercially available, low cost silica was an effective heterogeneous catalyst for the synthesis of solketalacetin as fuel additive. Moreover, it could be concludd the SBSA might also be a suitable catalyst for other chemical reactions requiring acidic catalysts.

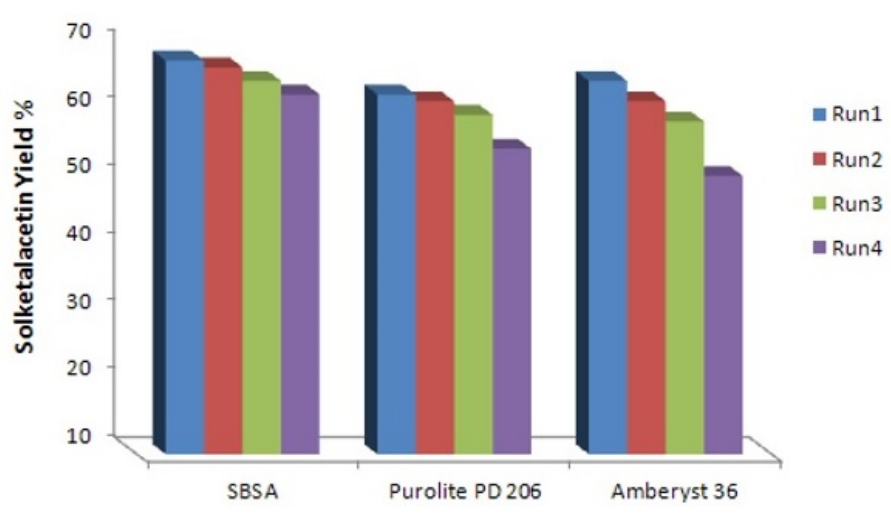

Fig.10. The solketalacetin yield (\%) of the Amberlyst 36, Purolite PD 206, and SBSA catalysts in four runs. Each catalyst was kept on-stream for $2 \mathrm{~h}$ in acetone to monoacetin molar ratio of 5 , $1.0 \mathrm{~g}$ catalyst, $40{ }^{\circ} \mathrm{C}, 1 \mathrm{bar}$, and $0.4 \mathrm{~mL} \cdot \mathrm{min}^{-1}$ feed flow rate.

\section{Conclusions}

The SBSA catalyst prepared from commercially available, low cost silica was found an effective catalyst for the synthesis of solketalacetin through the reaction of monoacetin with acetone. The catalytic activity and stability of SBSA was compared with those of Purolite PD 206 and Amberlyst 36 as two sulfonated catalysts. The increase in acetone to monoacetin molar ratio increased the solketalacetin yield for all used catalysts at $40{ }^{\circ} \mathrm{C}$, with the SBSA leading to the highest solketalacetin yield. In terms of stability, all three catalysts showed only a slight decrease in their activities after being on-stream for $24 \mathrm{~h}$. Moreover, the reusability tests revealed that the SBSA was more reliable compared with the other catalysts and was found stable after four consecutive runs.

\section{Acknowledgments}

This work was supported by Isfahan University of Technology.

\section{References}

[1] Bhorodwaj, S.K., Dutta, D.K., 2011. Activated clay supported heteropoly acid catalysts for esterification of acetic acid with butanol. Appl. Clay Sci. 53(2), 347-352.

[2] Cablewski, T., Faux, A.F., Strauss, C.R., 1994. Development and application of a continuous microwave reactor for organic synthesis. J. Org. Chem. 59 (12), 3408-3412.

[3] Chermahini, A.N., Omran, M.K., Dabbagh, H.A., Mohammadnezhad, G., Teimouri, A., 2015. Application of a functionalized mesoporous silica catalyst to the synthesis of tetrazoles. New J. Chem. 39(6), 48144820 .

[4] Deutsch, J., Martin, A., Lieske, H., 2007. Investigations on heterogeneously catalyzed condensations of glycerol to cyclic acetals. J. Catal. 245(2), 428-435.

[5] Fan, X., Burton, R., Zhou, Y., 2010. Glycerol (byproduct of biodiesel production) as a source for fuels and chemicals mini review. Open Energy Fuels Energy Sci. J. 3(1), 17-22.
[6] Ferreira, P., Fonseca, I.M., Ramos, A.M., Vital, J., Castanheiro, J.E., 2009. Esterification of glycerol with acetic acid over dodecamolybdophosphoric acid encaged in USY zeolite. Catal. Commun. 10(5), 481-484.

[7] Garcia, E., Laca, M., Perez, E., Garrido, A., Peinado, J., 2008. New class of acetal derived from glycerin as a biodiesel fuel component. Energy Fuels. 22(6), 4274-4280

[8] Garcia, E., Laca, M., Perez, E., Garrido, A., Peinado, J., 2008. New class of acetal derived from glycerin as a biodiesel fuel component. Energy Fuels. 22(6), 4274-4280.

[9] Goncalves, M., Rodrigues, R., Galhardo, T.S., Carvalho, W.A., 2016. Highly selective acetalization of glycerol with acetone to solketal over acidic carbon-based catalysts from biodiesel waste. Fuel. 181, 46-54.

[10] Goncalves, V.L., Pinto, B.P., Silva, J.C., Mota, C.J., 2008 Acetylation of glycerol catalyzed by different solid acids. Catal Today. 133-135, 673-677.

[11] Gorji, Y.M., Ghaziaskar, H.S., 2018. Continuous synthesis of a green fuel additive mixture with highest quantities of solketalacetin and solketal and lowest amount of diacetin from biodiesel-derived glycerol. J. Braz. Chem. Soc., 00, 1-7.

[12] Gorji, Y.M., Ghaziaskar, H.S., 2016. Optimization of solketalacetin synthesis as a green fuel additive from ketalization of monoacetin with acetone. Ind. Eng. Chem. Res. 55(25), 6904-6910.

[13] Guimaraes, A.D.M.F., Ciminelli, V.S.T., Vasconcelos, W.L. 2009 Smectite organo functionalized with thiol groups for adsorption of heavy metal ions. Appl. Clay Sci. 42(3-4), 410-414.

[14] Johnson, D.T., Taconi, K.A., 2009. The glycerin glut: options for the value-added conversion of crude glycerol resulting from biodiesel production. Environ. Prog. Sust. Energy. 26(4), 338-348.

[15] Kim, H.J., Kang, B.S., Kim, M.J., Park, Y.M., Kim, D.K., Lee, J.S. Lee, K.Y., 2004. Transesterification of vegetable oil to biodiesel using heterogeneous base catalyst. Catal. Today. 93-95, 315-320.

[16] Klepacova, K., Mravec, D., Bajus, M., 2005. tert-Butylation of glycerol catalyzed by ion exchange resins. Appl. Catal., A. 294(2), 141-147

[17] Krief, A., Provins, L., Froidbise, A., 1998. Diastereoselective synthesis of dimethyl cyclopropane-1,1-dicarboxylates from a yalkoxy-alkylidene malonate and sulfur and phosphorus ylides. Tetrahedron Lett. 39(11), 1437-1440.

[18] Kumar, D., Schumacher, K., von Hohenesche, C.D.F., Grun, M. Unger, K.K., 2001. MCM-41, MCM-48 and related mesoporous adsorbents: their synthesis and characterization. Colloids Surf., A. Physicochem. Eng. Asp. 187-188, 109-116.

[19] Lauriol-Garbey, P., Postole, G., Loridant, S., Auroux, A., BelliereBaca, V., Rey, P., Millet, J.M.M., 2011. Acid-base properties of niobium-zirconium mixed oxide catalysts for glycerol dehydration by calorimetric and catalytic investigation. Appl. Catal., B. 106(1-2), 94102.

[20] Maksimov, A.L., Nekhaev, A.I., Ramazanov, D.N., Arinicheva, Y.A., Dzyubenko, A.A., Khadzhiev, S.N., 2011. Preparation of highoctane oxygenate fuel components from plant-derived polyols. Pet. Chem. 51(1), 61-69.

[21] Melero, J.A., Van Grieken, R., Morales, G., Paniagua, M., 2007. Acidic mesoporous silica for the acetylation of glycerol: synthesis of bioadditives to petrol fuel. Energy Fuels. 21(3), 1782-1791.

[22] Miyatake, K., Iyotani, H., Yamamoto, K., Tesuchida, E., 1996. Synthesis of poly (phenylene sulfide sulfonic acid) via poly (sulfonium cation) as a thermostable proton-conducting polymer. Macromoleculs. 29(21), 6969-6971.

[23] Mota, C.J., da Silva, C.X., Rosenbach Jr, N., Costa, J., da Silva, F., 2010. Glycerin derivatives as fuel additives: the addition of glycerol/acetone ketal (solketal) in gasoline. Energy Fuels. 24(4), 2733-2736.

[24] Nanda, M.R., Yuan, Z., Qin, W., Ghaziaskar, H.S., Poirier, M.A., Xu, C.C., 2014. A new continuous-flow process for catalytic conversion of glycerol to oxygenated fuel additive: catalyst screening. Appl. Energy. 123, 75-81.

[25] Rastegari, H., Ghaziaskar, H.S., 2015. From glycerol as the by product of biodiesel production to value-added monoacetin by 
continuous and selective esterification in acetic acid. J. Ind. Eng. Chem. $21,856-861$.

[26] Rastegari, H., Ghaziaskar, H.S., Yalpani, M., 2015. Valorization of biodiesel derived glycerol to acetins by continuous esterification in acetic acid: focusing on high selectivity to diacetin and triacetin with no byproducts. Ind. Eng. Chem. Res. 54(13), 3279-3284.

[27] Rezayat, M., Ghaziaskar, H.S., 2009. Continuous synthesis of glycerol acetates in supercritical carbon dioxide using Amberlyst 15®. Green Chem. 11(5), 710-715.

[28] Sasikala, S., Meenakshi, S., Bhat, S.D., Sahu, A.K., 2014. Functionalized bentonite clay-sPEEK based composite membranes for direct methanol fuel cells. Electrochim. Acta. 135, 232-241.

[29] Shafiei, A., Rastegari, H., Ghaziaskar, H.S., Yalpani, M., 2017. Glycerol transesterification with ethyl acetate to synthesize acetins using ethyl acetate as reactant and entrainer. Biofuel Res. J. 4(1), 565-570.

[30] Shokrollahi, A., Zali, A., Pouretedal, H.R., Mousaviazar, A., 2012. Preparation of ordered sulfonated mesoporous polymer (OMP-TsOH) from p-toluenesulfonic acid and application in esterification reaction of fatty acids. J. Braz. Chem. Soc. 23(6), 1186-1192.

[31] Shirani, M., Ghaziaskar, H.S., Xu, C., 2014. Optimization of glycerol ketalization to produce solketal as biodiesel additive in a continuous reactor with subcritical acetone using Purolite ${ }^{\circledR}$ PD206 as catalyst. Fuel Process. Technol. 124, 206-211.

[32] Silva, P.H., Gonçalves, V.L., Mota, C.J., 2010. Glycerol acetals as antifreezing additives for biodiesel. Bioresour. Technol. 101(15), 62256229.
[33] Sivasankaran, A., Sangeeth, D., Ahn, Y.H., 2016. Nanocomposite membranes based on sulfonated polystyrene ethylene butylene polystyrene (SSEBS) and sulfonated $\mathrm{SiO}_{2}$ for microbial fuel cell application. Chem. Eng. J. 289, 442-451.

[34] Umbarkar, S.B., Kotbagi, T. V., Biradar, A.V., Pasricha, R., Chanale, J., Dongare, M.K., Mamede, A.S., Lancelot, C., Payen, E., 2009. Acetalization of glycerol using mesoporous $\mathrm{MoO}_{3} / \mathrm{SiO}_{2}$ solid acid catalyst. J. Mol. Catal. A: Chem. 310(1-2), 150-158.

[35] Van Gerpen, J., 2005. Biodiesel processing and production. Fuel Process. Technol. 86(10), 1097-1107.

[36] Zhou, L., Al-Zaini, E., Adesina, A.A., 2013. Catalytic characteristics and parameters optimization of the glycerol acetylation over solid acid catalysts. Fuel. 103, 617-625.

[37] Zhou, C.H.C., Beltramini, J.N., Fan, Y.X., Lu, G.Q., 2008. Chemoselective catalytic conversion of glycerol as a bio renewable source to valuable commodity chemicals. Chem. Soc. Rev. 37(3), $527-549$

[38] Zhou, L., Nguyen, T.H., Adesina, A.A., 2012. The acetylation of glycerol over amberlyst-15: kinetic and product distribution. Fuel Process. Tech. 104, 310-318.

[39] Sasikala, S., Meenakshi, S., Bhat, S.D., Sahu, A.K., 2014. Functionalized bentonite clay-sPEEK based composite membranes for direct methanol fuel cells. Electrochim. Acta. 135, 232-241. 